LOCAL-SHARE COMMUNITY COLLEGE FINANCE

\title{
Equity and Efficiency of Community College Appropriations: The Role of Local Financing
}

\author{
Alicia C. Dowd \\ University of Massachusetts Boston \\ John L. Grant \\ Cape Cod Community College
}

\begin{abstract}
Alicia C. Dowd, Department of Leadership in Education, University of Massachusetts Boston; John L. Grant, Office of Institutional Research and Development, Cape Cod Community College.

Sections of this paper were presented in earlier drafts at the Cornell Higher Education Research Institute’s (CHERI) “Complex Community College” conference (October, 2003) and the Association for Institutional Research’s Annual Forum (May, 2003). The authors wish to thank Jeff Groen and Jane Wellman for their review of the earlier draft presented at the CHERI conference.

Correspondence concerning this article should be addressed to Alicia C. Dowd, Assistant Professor, Graduate College of Education, University of Massachusetts Boston, 100 Morrissey Blvd., Boston, Massachusetts 02125. E:mail: alicia.dowd@umb.edu.
\end{abstract}




\begin{abstract}
The study analyzes the equity of community college financing and demonstrates intrastate variations in appropriations to community colleges. The ratio of $90^{\text {th }}$ to $10^{\text {th }}$ percentile values ranges from 2.0 to 2.8 in half the states analyzed, levels which are considered high in comparison to K-12 finance inequities. In 10 states with high revenue disparities, the direction of revenue deviations is more often progressive in state-funded than in local-share states, suggesting the local role may undermine equity. Differences in economies of scale, geographic costs, and program costs are explored as factors determining funding disparities.
\end{abstract}


Over two decades ago, Breneman and Nelson posed the question, "Should Serrano Go to College?” (1981). The authors of Financing Community Colleges were referring to the landmark case of Serrano v. Priest, which was decided in the California State Supreme Court in 1971. The Serrano decision found the California school financing system unconstitutional under the equal protection provision of the state constitution. The educational resources provided to students depended on the wealth of the neighborhoods in which they lived, a fundamentally unjust arrangement stemming from the tradition of local control and local financing. Breneman and Nelson concluded that, similarly, the local finance role for community college systems likely creates resource disparities that disadvantage students in less affluent communities (p. 126). As in primary and secondary school (K-12) finance, approximately half the states in the United States have a local government finance role for funding community colleges. Colleges serving areas with a weak economic base that rely on local property or other taxes for a share of their revenues will receive lower revenues than peer colleges located in wealthier areas of their state, creating an inequitable finance system.

Three decades after Serrano, which set off waves of school finance litigation and reform across the United States (Verstegen, 1998), the effect of local control on school finance equity is still a matter of contentious debate and legal action. ${ }^{1}$ In contrast, since Breneman and Nelson's consideration of community college finance equity, and a similar study at that time by Garms (1981), the role of local control in community college finance systems and its effect on equity has received comparatively little attention. This may be due to the fact that the authors concluded community college finance equity is a less pressing issue than school finance equity because a college education is not 
compulsory, nor "essential for functioning or succeeding in life" (p. 124). In addition, Breneman and Nelson (1980, p. 174) argued the efficiency benefits of local control: those who are most likely to take advantage of a community college have the opportunity to express their educational preferences through the local governance and tax system. Further, the task of disentangling geographic and program cost differentials across colleges in a state, economies of scale on large and small campuses, and the impact of student college choice and their effects on measures of resource equity presents a daunting challenge that may have inhibited study of this topic. With funding coming from state, local, and federal governments and from the private sector in the form of tuition, fees, and philanthropic donations, community college finance systems are relatively more complex than K-12 finance systems.

Nevertheless, even in an era when efficiency rhetoric dominates the politics of public finance (Alexander, 2000; Dowd, 2003), the issue of community college finance equity has not entirely faded. Several state-level reports provide evidence that wide variations do exist in the level of resources allocated to community colleges and that finance equity is a concern of state policy analysts (Budget development approach/options and impact of formula/fair share funding, 2000; Community colleges and the State University of New York, 1999; Iowa Community College funding formula task force report, 1998). The Education Commission of the States (State Funding, 2000) issued a comprehensive state-by-state portrait of community college finance systems and highlighted policy questions that arise from the local finance role, including the issue of equal access to postsecondary education within states (p. 10). In a paper updating the application of the economic tenets of equity and efficiency to an analysis of community 
college finance, Romano (2003) highlights local taxes as more regressive than state and federal taxes, because they rely on property taxes, rather than more progressive income taxes. Flores (2003) analyzed state community college finance data from Texas and found inequities in the funding of Hispanic Serving Institutions located on the U.S.Mexican border. Most recently, in a case with arguments echoing K-12 finance litigation, three community colleges in Oregon challenged the state's equalization formula, arguing that it was unfair to penalize colleges that received relatively high local property-tax revenues. In November, 2003, a circuit-court judge ruled against the plaintiffs, upholding the right of the Board of Education to determine the funding formula. The decision did not directly rule on the equity of the finance system and the colleges have said they plan to appeal (Gomstyn, 2003).

In a trend perceived as equity enhancing, the local share of income for community colleges has declined over time (Breneman \& Nelson, 1981; State Funding, 2000). From 1950 to 1997 , it decreased on average from $49 \%$ to $19 \%$, while the average share of state revenue increased from $26 \%$ to a high of $60 \%$ in 1980 , before declining to $44 \%$ in 1997 (Romano, 2003, Table 3). The view that financing systems are more equitable under state control is consistent with the direction of court-ordered school finance reforms, which have often mandated “power-equalizing” roles for state governments to redistribute resources among school districts of disparate wealth.

While a community college education is not compulsory and states do not have a legal obligation to provide equitable postsecondary schooling resources, as they do for primary and secondary schooling, there is, perhaps, a growing sense that an associate's degree is today the minimal credential necessary to attain social and economic security. 
This view is reflected in the rhetoric that surrounded Bill Clinton's initial proposal for the federal Hope Scholarship. In his acceptance speech at the Democratic National Convention in 1996, Clinton proposed a tax credit for the first 2 years of college to “make at least two years of college as universal as four years of a high school education is today” (Clinton acceptance speech, 1996). That the implementation of the “scholarship” as a tax credit provided a boon for the middle class more than it helped low-income students enter college (Tax benefits, not financial aid, 2003) demonstrates the tension between the rhetoric of access and the politics of resource distribution. The growing importance of a college education and heightened conflicts over financial resources suggests that the equity of community college financing systems deserve greater national consideration. This study contributes to that goal by analyzing the local role, which is generally viewed as an equity-reducing component of finance systems, in resource distribution to community colleges within state systems.

Based on national data, this study characterizes current intrastate variation in revenues from state and local sources to community colleges and analyzes differences and similarities in distribution patterns in states with and without local-share financing. The following questions are addressed:

1. How much do college revenues per student vary within state systems?

2. Is local share funding associated with higher or lower revenues per student?

3. Is local share funding associated with higher intrastate variation in tuition and fees?

4. Is local share funding associated with higher intrastate variation in revenues per student? 
Questions 1 and 2 focus on descriptive information to establish the context of revenue disparities. Question 3 evaluates the relationship between local funding and variation in tuition in fees to test a conclusion presented in the ECS (2000) community college financing report, where the authors observed: "Dramatic differences in property tax valuations across a state can lead to large disparities in tuition rates between wealthier communities and poorer districts, because poorer districts may be forced to raise tuition and fees to meet their basic budgets” (State Funding, 2000, p. 10). Greater variation in tuition and fees is therefore expected in states with local financing. Question 4 is motivated by the assumption that states that rely strictly on state funding will have lower variation in revenues than states with local shares, due to the equalizing effects of the state role. As high variation in state-funded states may be created by power-equalizing formulas, which are intended to direct greater than average funds to colleges with highneed students, the relationship between funding disparities and community wealth is also examined.

The study focuses on local and state appropriations and tuition and fees, which are the largest sources of revenues for community colleges. Other sources of funding may well have an impact on finance equity, but these effects are not addressed here. The purpose of the study is to document revenue disparities and present descriptive statistics and graphs that facilitate comparisons of revenue distribution patterns in local-share and state-funded states. The study serves as a starting point for future state-level analyses by supporting purposeful sampling of states with similar and dissimilar funding patterns. It fills a gap in the literature by providing a systematic national analysis of contemporary community college funding patterns with a focus on the role of local financing. 


\section{Conceptual Framework}

The distribution of financial resources to community colleges within a state is conceptualized as determined by rational and political factors. Rational factors include per capita funding and cost adjustments for urbanization, economies of scale, and program type. These rational systems are understood to be modified by "politically mobilized and well-connected groups," who garner a greater share of resources through political means (Timar, 1994, p. 144). These political forces can have equitable effects, as in the creation of categorical aid for students with high educational need, or inequitable effects, as in the flow of funds to wealthy suburbs. The conceptualization of equitable funding is based on the scholarship of school finance (Monk, 1990; Odden \& Picus, 2004; Verstegen, 1998; Wong, 1994) and community college finance equity (Breneman \& Nelson, 1981; DesJardins, 2002; Garms, 1981). Equal funding for students with equal needs is understood to create "horizontal equity," while the provision of greater resources for students with greater need contributes to "vertical equity."

Recent research by Hoxby (2001), Metzler (2003), and Timar (2003) shows that court-ordered finance reform is often an ineffective tool to counter finance inequities. Their studies indicate that rational resource allocation systems are undermined by political lobbying and individual choices in educational markets. Therefore, rational policies are understood to be counteracted by political systems operating at both the local and state levels.

\section{Data and Methods}

A subsample of data from the national 2000-2001 Integrated Postsecondary Education Data System (IPEDS) Finance survey is analyzed. IPEDS is a census survey of 
higher education institutions in the United States. Because IPEDS is a census and the analyses are descriptive, the data are treated as population rather than sample data, and tests of statistical significance are not presented for observed differences in values. The sample is limited to those categorized in IPEDS as two-year public colleges that are not technical colleges (omitting those in the U.S. territories). ${ }^{2}$ Since the focus is on variation in revenues to colleges within a state, states reporting financial data on fewer than 5 community colleges are excluded, omitting 15 states. ${ }^{3}$ Technical colleges were omitted because technical programs often carry greater costs for equipment and materials. While this step restricts the institutional type, it does not completely omit technical programs, which are also offered in community colleges. The remaining sample includes 705 community colleges with non-missing data in 35 states.

The primary focus is on appropriations from state and local governments. To compare revenue across colleges with different enrollments, appropriations per full-time equivalent student (FTE) are analyzed. ${ }^{4}$ Colleges are categorized in five local fundingshare categories based on the ratio of local appropriations to state appropriations. Based on the distribution of colleges in these five categories, states are designated as primarily local-share funded or state-funded.

Variation in local and state appropriations is measured by deviation from the median value for each state. Median values are used as the measure of central tendency, because the means are affected by outliers that may be colleges with a special mission or funding. Similarly, dispersion is measured by statistics that are not affected by extreme values, including the interquartile range $(I Q R)$ and the ratio of $90^{\text {th }}$ to $10^{\text {th }}$ percentile values. The mean of absolute revenue deviations for each state provides a summary 
statistic of variation for comparison across states. A college's position above or below the median of state and local appropriations within the state is also represented by an index of the college's revenue divided by the state median. The index is an expression of revenue deviations that is not sensitive to the differing magnitudes of spending in states. To test the direction of revenue deviations as flowing towards relatively wealthy or poor communities, the proportion of full-time students at each college who receive federal grant aid is used as a measure of community wealth. A college’s geographic locale is indicated with an ordinal variable with seven categories ranging from large city to rural.

\section{Limitations}

There are several important limitations of the research design. First, the study does not directly account for state-level differences in community college history, mission, status, governance, and finance structure. Local funding is treated as evidence of a local political role, but the nature of state and local political structures are not investigated. For this reason, revenue disparities are measured at the state level and descriptive statistics summarizing revenue deviations are presented by state. This step facilitates the review of the findings by knowledgeable analysts at the state level. Second, while all surveys are subject to measurement error, with hundreds of institutional researchers and administrators across the country entering complex financial data, IPEDS may suffer this problem even more greatly than usual. While noting this limitation, it is important to recognize that IPEDS is the primary national collection of college financial data. Analyses of the type reported here that may reveal significant measurement error may serve to strengthen this major data source. 
The percentage of full-time students at a college receiving federal financial aid is used as a proxy for community wealth. Variation in tuition and fees, which occurs both across and within states, partially determines who qualifies for financial aid. Both financially needy students and students attending more expensive colleges are more likely to be eligible for aid. Therefore, the analysis is restricted to intrastate differences in the proportion of students receiving grant aid and to states where the correlation between tuition and aid is weak. The use of the financial aid variable as a measure of community wealth was also evaluated using Census data from New York State and Massachusetts, where colleges were matched to the county or counties in which they are located. Using logarithmic transformations to correct for skewed distributions, the Pearson correlation between aid and the percentage of children in poverty was moderately strong at $r=.766$ and $r=.614$ in New York State $(n=32)$ and Massachusetts $(n=15)$, respectively.

Finally, the study uses the NCES’ FTE measure, in which three part-time students are treated as equivalent to one full-time student, to compare per capita funding. This measure is not sensitive to potential differences in the resource needs of campuses with high and low proportions of part-time students and may not be equally appropriate to campuses serving different populations of students. Alternative measures of student enrollment may produce different results concerning resource disparities among campuses.

\section{Results}

In this sample of U.S. community colleges, state appropriations are the largest source of all revenues with a mean share of $38 \%$. Tuition and fees contribute $20 \%$ and federal grants and contracts 13\%. Including colleges with zero local share, local 
appropriations average $13 \%$. The local share contingent on non-zero local funding increases to $20 \%$ and the state share is reduced to $34 \%$. Auxiliary revenues contribute $6 \%$ and state grants contribute 5\%. Other sources of revenue such as private gifts and local grants contribute $3 \%$ or less, on average.

The mean value of total revenues from all sources except tuition and fees per FTE is $\$ 8,230$, with a standard deviation $(S D)$ of $\$ 3,800$. The mean value of state and local appropriations per FTE is $\$ 5,180$ ( $S D=\$ 2,440)$. The median of this skewed variable is $\$ 4,740$. Average tuition and fees are $\$ 1,400$ ( $S D=\$ 717)$. Table 1, which presents the median and interquartile range of state and local appropriations per FTE by state, reveals a great deal of variation both within and across states. In 16 states in the sample, the median value is zero local appropriations. A review of the full range of values indicates that in ten states no colleges received local funding.

Five categories of local funding share were created based on the ratio of local appropriations to state appropriations. These categories, which were created based on the overall distribution of ratios as shown by a histogram, encompass local share funding ratios of 0.0-0.01 $(n=268), 0.02-0.50(n=199), 0.51-1.0(n=121), 1.01-2.0(n=70), 2.1$ and above ( $n=47)$. Colleges within the same state may appear in different local funding share categories, because the ratios differ by college. Table 2 shows the distribution of colleges within the local share categories by state, divided into 17 "local-share" and 17 "state-funded" states, inclusive of 256 and 368 colleges, respectively. States were designated as local-share funded when at least $75 \%$ of the colleges reported ratios greater than 0.02. All local-share states also have state funding. 
In some states, such as Connecticut, Florida, and Georgia, colleges consistently report no local funding. Five states-Alabama, Arkansas, Colorado, Ohio, and Oklahoma—are dominantly state funded, but have 2 or more cases reporting local funding. In 2 of these states, Arkansas and Ohio, local taxes may be raised and used to fund community colleges, but the majority of districts did not do so in 2000. In Colorado, 2 junior colleges previously funded by their local districts were recently incorporated into the state system and uniquely continued to receive local funding (State Funding, 2000, p. 12-13). The "local-share" designation is applied to states where local funding is a regular component of the funding system. In states with a local funding role, such as Illinois, Kansas, and Maryland, colleges are distributed across the funding share categories. California colleges report local funding share across the five categories. However, California is analyzed separately due to the large number of colleges and the unique funding system in the state. ${ }^{5}$

Table 3 presents the mean and standard deviation of tuition and fees and the percentage of students receiving federal grant aid, by local funding category and by state. The tuition burden placed on students varies considerably, from a low of \$314 in California to a high of $\$ 2,650$ in Ohio. As indicated by the standard deviations, there is considerable variation in tuition and fee charges within states. ${ }^{6}$ State-funded states have higher mean tuition, $\$ 1700$ ( $S D=\$ 555)$, than local-funded states, which have a mean tuition of $\$ 1479$ and higher variation $(S D=\$ 638)$. In Figure 1, the boxplots show the range and IQR of tuition and fees by state for state-funded and local-share states. The vertical lines indicate the location of the states in the distribution. Whether assessed by the range or $I Q R$, local-share states have greater variation in tuition and fees. The median 
range and $I Q R$ in local-share states are $\$ 1412$ and $\$ 300$, both more than double the respective values of $\$ 713$ and $\$ 138$ in state-funded states.

The mean proportion of students receiving grant aid ranges from a quarter to half, with the lowest standard deviation at 8\% and typical values ranging between 10 to $19 \%$. This indicates that in all states the dispersion of the grant aid variable is sufficient to distinguish the relative wealth of the college's local community. The mean and standard deviation of grant aid receipt is similar in state- and local-funded states, at 35\% ( $S D=16 \%)$ and $38 \%(S D=18 \%)$, respectively. The value in California where tuition is low is also relatively low at a mean of $29 \%(S D=15 \%)$.

The upper panels of Table 4 and Figure 2 illustrate that colleges in the zero local share category have the lowest median appropriations, which at $\$ 4,259$ is roughly $\$ 400$ to \$1000 less per FTE than the median value of any of the local share categories. With an inter-quartile range only slightly higher or less than the other categories, the $75^{\text {th }}$ percentile value for zero local-share colleges is always less than the $75^{\text {th }}$ percentile in the other categories, and in some comparisons is closer to the median value for colleges receiving local appropriations. Only one college with local funding has per FTE appropriations less than the lowest values in the zero-share category. Typically, then, colleges that receive local funding have higher levels of appropriations per FTE from state and local sources than do colleges that receive state-level appropriations only.

The lower panel of Table 4 and Figure 2 illustrate these analyses using a measure of revenues per FTE from all sources, excluding tuition and fees. Colleges in the zero local-share category no longer have the lowest median value. At a median of $\$ 7,454$ and $I Q R$ of $\$ 3,132$, the distribution is very similar to that for colleges in the local-to-state 
appropriations ratio categories of 0.51-1.0 and 1.1-2.0. Colleges reporting a local-share ratio of 0.02-0.50 have the highest distribution of revenues from all sources per FTE, with a median value $\$ 1000$ greater than that for colleges with no local share. The colleges with a local share greater than 2.0 have a high median, but also have a high $I Q R$, which makes the overall distribution similar to the zero-share category. Typically, then, colleges with no local appropriations have similar levels of total revenue as colleges with local appropriations, with the exception of those colleges in the smallest local-share category.

Table 5 reports, by state within the local- and state-share funding categories, the extent to which the FTE funding received by colleges from local and state appropriations varies within states. Five states each have one case reporting revenues more than double the $95^{\text {th }}$ percentile value in the state. These have been treated as extreme, unique values and omitted from the estimates of average revenue deviations. ${ }^{7}$ The mean (absolute value) deviation of revenues from the state median is $\$ 973(S D=\$ 314)$ per FTE, excluding California, which has a mean deviation of $\$ 1330$. The ratio of appropriations at the $90^{\text {th }}$ percentile to the $10^{\text {th }}$ percentile is equal to or greater than 2.0 in 13 of the 26 states. The majority of states exceed an IQR of \$1,000 per FTE and 15 states have an IQR greater than $\$ 1,500$.

Local-share funding is associated with slightly higher intrastate variation of local and state appropriations per FTE. The upper panel of Table 6 and Figure 3 compare the distribution of average absolute deviations per FTE measured in dollars by local-share and state-funded states. ${ }^{8}$ At $\$ 904$, the median deviation in local-share states is $\$ 100$ more than the median value of $\$ 807$ in state-funded states. The $25^{\text {th }}$ percentile in local-share states (\$846) is also higher than the median value in state-funded states. One hundred 
dollars is $2 \%$ of the mean value of $\$ 5,000$ of state and local appropriations per FTE.

Thus, while variation is typically larger in local- than in state-funded states, the revenue disparities at the center of the distribution are not great. Above the median, local-funded states cluster near a $75^{\text {th }}$ percentile value of $\$ 1350$, while state-funded states fall around a lower $75^{\text {th }}$ percentile value of $\$ 1081$. This difference in variation, nearing $\$ 300$, is greater, but still a relatively small proportion of typical state and local appropriations.

The larger variation in revenues in local-share states is in part due to higher levels of spending in those states. When revenue deviations are indexed by college as a proportion of the state median (see the lower panel of Table 6), the distribution is quite similar under both funding types, with the exception that the index for local-share states has a higher maximum value. In addition, as shown by Figure 3, the local-share category does include 6 of 17 states with an average deviation lower than the median in the statefunded category, which indicates that variation in local-share states is not uniformly high. Similarly, 6 states without a local role have an average deviation greater than $\$ 900$, the midpoint of deviations in local-share states, which indicates high revenue deviations are found in states with no local role.

To assess the hypothesis that revenue deviations in state-funded states promote vertical equity by providing higher levels of funding to communities with greater need, while deviations in local-funded states are regressive, an average funding deviation of $\$ 1000$ was selected as a threshold for designating "high disparity” states. This designation encompasses 5 state-funded states (Arkansas, Colorado, Florida, Georgia, and Minnesota) and 6 local-funded states (Kansas, Maryland, Michigan, North Carolina, New Mexico, and Texas) ${ }^{9}$. Revenue deviations in these states were graphed against the 
proportion of full-time first-time students at each college receiving federal grant aid. Since the grant aid proportion is intended to serve as a proxy for community wealth, the Pearson's correlation between tuition and fees and grant aid was first obtained for each state. The correlation between these two variables was relatively weak, ranging from $r=.11$ to $r=.23$, with the exception of Arkansas and Colorado, where the values were $r=.28$ and $r=.47$, respectively. Colorado was excluded from the analysis to eliminate variation in tuition as a strong alternative explanation for differences in the proportion of students receiving financial aid.

Scatterplots graphing revenue deviations by the proportion of students receiving grant aid are presented for state-funded states in Figure 4 and local-share states in Figures 5 and 6 . The case markers indicate the geographic locale of the college to simultaneously assess if revenue deviations may be attributed to geographic cost differences or economies of scale. Revenue deviations in Minnesota are strongly correlated with grant aid receipt $(r=.80)$. In addition, all colleges with positive revenue deviations are located in small towns, while most with negative deviations are located in the fringe of large cities, suggesting economies of scale for larger campuses. Deviations are more weakly, but positively, correlated in Florida $(r=.35)$ and Arkansas $(r=.12)$, where, in the latter case, the low value does not provide a good summary. The graph for Arkansas shows a stronger linear relationship with the exception of an unusual case with high positive revenue deviations and a relatively small proportion of grant recipients. In both these states, small towns tend to have positive deviations. In contrast, the correlation in Georgia is negative $(r=-.26)$. Colleges with lower proportions of grant recipients have positive revenue deviations. Small towns appear both above and below the median line. 
In local-share states, Michigan and North Carolina (Figure 5) have positive correlations with grant receipt ( $r=.31$ and .19 , respectively). Rural and small towns appear both above and below the median line in both states. Maryland (Figure 6) has a positive correlation of $r=.39$, but this high value is strongly affected by one rural college with high positive deviations and high grant receipt. The association between funding and need in Maryland is much weaker among the remaining cases. Similarly, Kansas, New Mexico, and Texas have weak correlations, at $r=.13, .10$, and .08, respectively. In Texas, all but 1 of 6 colleges with more than $70 \%$ of students receiving grant aid have positive revenue deviations, but many colleges with lower proportions of grant recipients show equivalent or higher positive deviations. In California (not shown), where the average absolute revenue deviation is $\$ 1330$, there is no correlation between revenue deviations and grant receipt ( $r=.01)$. In summary, while deviations in 3 of 4 state-funded colleges are positively associated with grant aid, this relationship is found in only 2 of 6 local-share colleges. Positive revenue deviations in state-funded states are also more consistently associated with smaller geographic locales, suggesting economies of scale are at play in these states.

\section{Discussion}

This study examines several questions about the impact of local funding on community college finance equity. Community college systems in half of the United States have a structure similar to K-12 finance systems in that they rely on local governments for funding. By analogy between community college and K-12 finance structures, it was hypothesized that local funding in community colleges creates revenue disparities that disadvantage the least affluent communities in a state. 
Analyzing the federal IPEDS 2000-2001 finance data in 35 states, the study demonstrates that significant intrastate revenue disparities do exist. The average amount of appropriations from local and state governments for community colleges is $\$ 5,000$ per FTE. The average of the absolute value of college revenue deviations from the state median is close to $\$ 1,000$, approximately $20 \%$ of typical appropriations. The majority of the 35 states analyzed have an inter-quartile range of revenue disparities greater than $\$ 1,500$ per FTE. In half of the states analyzed, the ratio of appropriations at the $90^{\text {th }}$ and $10^{\text {th }}$ percentiles falls in the range of 2.0 to 2.8 . In comparison, Wong (1994) characterizes spending disparities between high and low revenue K-12 districts of 2.6 in New York, 3.1 in Illinois, and 2.8 in Texas as among the “most severe” (p. 277), based on a 1990 report by the Congressional Research Service.

Though not as pronounced as these K-12 disparities, the size of community college revenue disparities in many states may nevertheless be considered quite substantial. Further analysis is required to determine where these disparities may be attributed to different combinations of general education, vocational, remedial and other programs across campuses in a state. Several states employ weighting schemes in their funding formulas, based on cost studies of different fields of instruction, in which technical and remedial courses receive 1.5 to 2.0 times the funding of general education courses (State Funding, 2000).

Revenue variations tend to be larger in states with a local finance role, but the difference is a small proportion of total funding and is due in part to higher levels of appropriations in those states. Taking into account this broader context, state-and localfunded states have quite similar levels of revenue variation. However, some resource 
disparities are progressive, or equity enhancing, while others are regressive. To assess the equity of resource differences, a sub-sample of 10 states with average absolute deviations exceeding \$1000 per FTE was examined further. Revenue deviations in these high disparity states were observed as equity enhancing in 3 of 4 state-funded states and in 2 of 6 local-share states, suggesting that local funding is more often, though not always, regressive. Since all local-share states also have state funding, these differences in funding patterns cannot be attributed exclusively to the local role, but may be understood to result when local funding is commingled with state funding. Thus, the direction of revenue disparities, not the overall level, presents a cause for concern.

The results support theoretically based equity and efficiency arguments regarding the effects of a local role on community college finance. The local finance role appears to create revenue disparities that do not promote vertical equity. On the other hand, localshare states tend to have lower tuition and higher levels of funding from within-state sources, which may reflect the "efficient” nature of local voters supporting their local colleges. Colleges with a ratio of local appropriations to state appropriations less than one-half also have the highest levels of revenues from all sources, excluding tuition and fees. This suggests that when local governments have responsibility for funding community colleges in collaboration with state governments, students benefit from a broader revenue stream. With government officials at both the state and local level having a stake in the success of the local college, lobbying on behalf of the college and support for entrepreneurial activities may well increase.

These findings have implications for community college finance systems. States with a local finance share subordinate to the state share appear to benefit in terms of 
higher revenues. It appears that intrastate variation in the resources available to a college in these states is also less likely to be determined by "rational” planning objectives, such as budget adjustments for low-income students or economies of scale. This situation may be socially beneficial if local financing contributes to a "leveling up" of resources, where all colleges benefit from higher public funding than they would in the absence of the local contribution. This implies that states with an existing local finance role should maintain them, while adopting policies that tax relatively high local revenue districts to provide additional funds to low revenue districts. As Hoxby (2001) has shown in her analysis of the "leveling up” and "leveling down” effects of K-12 finance reforms, the tax price on high wealth districts should not be so high as to provide a disincentive for local funding in those districts, otherwise the equalization policy may, in fact, depress funding. As state funding decreases, even states without a traditional local finance role are placing greater expectations on individual colleges to generate additional funds, whether through academic entrepreneurship, auxiliary business activities, or fundraising (Burke \& Serban, 1998). These efficiency initiatives have the potential to raise additional revenues, but also create equity concerns as the state role in allocating resources diminishes. These states should also incorporate resource-sharing policies into incentive plans.

It is important to note that several factors for which controls have not been included due to data limitations may affect the interpretation of the findings. Most important, the observed correlation between positive revenue deviations and the proportion of students receiving grant aid may have meanings other than the equityenhancing effect ascribed to it in this analysis. The proportion of students receiving grant aid may be affected by access to information and counseling regarding financial aid or by 
clarity of purpose among first-time students. If such factors are decisive in determining the proportion of grant recipients at a college, the positive correlation between higher levels of local and state appropriation and grant receipt may be indicative of revenue disparities in favor of more affluent communities with higher levels of college-related information and networking, or “social capital” (Coleman, 1988). In future analyses, the use of the IPEDS federal grant receipt variable should be supplemented with Census income and poverty data to provide a better control for community wealth.

The higher levels of funding going to small town colleges in some states have been interpreted here as compensating for diseconomies of scale. However, determining whether observed revenue disparities are appropriate for that purpose requires more information about fixed and variable costs and controls for geographic price differences between urban, suburban, and rural areas. Higher costs in urban areas are likely to diminish the purchasing power of each dollar in revenue. This means that for more accurate comparison revenue differences must be adjusted by a cost index similar to those developed for studies of K-12 finance equity. Generally, it is expected that the use of a geographic index will shift state funding from rural to urban areas (Carey, 2003; Odden \& Picus, 2004). With significantly greater appropriations per FTE awarded to rural and small colleges in several of the high disparity states, it is important to evaluate whether the appropriation premiums for small size are based on actual cost differences. Such estimates are clearly politically sensitive, as they have the potential to significantly shift funding among institutions. In states where white residents are disproportionately located in small towns and students of color in urban areas, the higher funding for small towns may be due to racial group politics and disparities in legislative power. Complex 
interactions may also be at play. Flores (2003) shows that Texas’ funding formula and reliance on local-share funding results in both higher and lower funding for Hispanic Serving Institutions (HSIs) in communities providing a threshold tax rate. The majority of the HSIs receiving the short end of the deal are located on the U.S. Mexican border. As discussed above, some portion of the revenue disparities may be due to the location of high cost programs, but there may be differences, too, in the geographic accessibility of students to those programs. States may locate specialized programs requiring technical facilities at a small number of campuses and expect mobile adults to travel to them, but this may not be a realistic option for students constrained by work and family commitments. Thus, while high cost programs may explain some portion of the funding disparities, their location may also raise equity issues in regard to program access.

K-12 finance equity cases initially focused on inputs, but over time the judicial focus has shifted to promoting equitable student outcomes. This approach is termed “adequacy,” and it holds states accountable for providing resources to schools sufficient to enable students to meet educational standards and become successful competitors in a global economy (Verstegen, 1998). The incorporation of adequacy standards into community college finance analyses would be consistent with the recent policy focus on higher education performance accountability (Dowd, 2003). An adequacy, or "outcome equity,” approach shifts the question from "Is equitable funding being provided to colleges in the state?” to “Are equitable program completion rates being achieved?” The answer to the latter question implies disparate funding because students with greater educational needs will require greater resources. For example, a college enrolling a 
relatively high proportion of immigrants in a nursing degree program may well require resources to provide language tutoring to attain graduation rates equal to those of a program enrolling native English speakers. This example underscores the significance of such funding decisions when we consider the shortage of bilingual and ethnically diverse nurses in the United States (Butters, 2003). Similarly, as community colleges take on an increasing role in remedial education, it is important to ask what levels of resources are needed to successfully educate students to desired standards of achievement.

This study has focused on states with high revenue deviations. However, it should also be noted that states with low funding disparities may have inequitable systems if students with unequal needs are being treated as equals by the financing system. In addition, absent state-by-state information about unique programs and institutional missions, the analysis has focused on conservative measures of variation that were not determined by extreme values. This approach may have minimized the characterization of funding inequities in some states. Half of the states in the sample have $90^{\text {th }}$ percentile revenue deviation values greater than $\$ 1900$, which may be deserving of greater attention. Does the high funding for these institutions stem from unique institutional histories, unusual levels of political clout, data-reporting error, or rational planning decisions to efficiently locate high costs programs? The study reported here provides a foundation for future multivariate analyses and purposeful sampling for case studies. State analysts and institutional researchers may wish to replicate the results for their state using IPEDS and state data. The following factors should be considered when evaluating the equity of revenue disparities: economies and diseconomies of scale, geographic price 
differences, mix of program types, community and student racial and demographic characteristics, and program completion rates.

Notwithstanding the recent community college finance litigation in Oregon (Gomstyn, 2003), determination of what constitutes “fair” intrastate community college resource allocations will most likely depend on political processes, rather than on legal decisions like those that have so significantly shaped K-12 finance. While primary and secondary schooling are a constitutional right mandated by state law, postsecondary education is not. Today, however, many would argue that a community college education now sets the contemporary standard for full participation in the economic and democratic institutions of our country. If this rhetorical claim gains political support, then it could also be argued that states have a responsibility to fund community colleges according to adequacy, or “outcome equity” standards. Many community college students have limited options as to where they attend college, constrained as they often are by family responsibilities, employment obligations, and financial hardship. Under these conditions, the funding disparities documented in this paper are certainly deserving of greater understanding through academic analysis, action research by community college practitioners, and political debate within states. 


\section{References}

Alexander, F. K. (2000). The changing face of accountability. Journal of Higher Education, 71(4), 411.

Bill Clinton's view on education, from acceptance speech. (1996). Retrieved December 19, 2003, 2003, from http://www.chronicle.com

Breneman, D. W., \& Nelson, S. C. (1981). Financing community colleges: An economic perspective. Washington: The Brookings Institution.

Budget development approach/options and impact of formula/fair share funding. (Budget Request Framework Proposal)(2000). Boston, MA: Board of Higher Education.

Burke, J. C., \& Serban, A. M. (Eds.). (1998). Performance funding for public higher education: Fad or trend? San Francisco: Jossey-Bass.

Butters, C. (2003). Associate Degree nursing students: A study of retention in the nursing education program. Unpublished Dissertation, University of Massachusetts Boston, Boston, Massachusetts.

Carey, K. (2003). The funding gap: Low-income and minority students still receive fewer dollars in many states. Retrieved December 15, 2003, from http://www2.edtrust.org/EdTrust/Product+Catalog/special+reports.htm\#2003

Coleman, J. S. (1988). Social capital in the creation of human capital. American Journal of Sociology, 94(Supplement), S95-S120.

Community colleges and the State University of New York. (1999). Boulder, Colorado: National Center for Higher Education Management Systems.

DesJardins, S. L. (2002). Understanding and using efficiency and equity criteria in the study of higher education policy. In J. C. Smart \& W. G. Tierney (Eds.), Higher 
education: Handbook of theory and research (pp. 173-219). New York: Agathon Press.

Dowd, A. C. (2003). From access to outcome equity: Revitalizing the democratic mission of the community college. Annals of the American Academy of Political and Social Science, 586(March), 92-119.

Flores, S. (2003, November 14). Disproportionate policies: Latino access to community colleges in Texas. Paper presented at the Association for the Study of Higher Education, Portland, Oregon.

Garms, W. I. (1981). On measuring the equity of community college finance. Educational Administration Quarterly, 17(2), 1-20.

Gomstyn, A. (2003). Oregon judge rejects community-colleges' lawsuit seeking more state money. Retrieved November 17, 2003, from http://chronicle.com

Hoxby, C. M. (2001). All school finance equalizations are not created equal. Quarterly Journal of Economics(November), 1189-1231.

Iowa Community College funding formula task force report. (1998). Iowa Department of Education.

Metzler, J. (2003). Inequitable equilibrium: School finance in the United States. Indiana Law Review, 36(Spring).

Monk, D. H. (1990). Educational finance: An economic approach. New York: McGraw Hill.

Odden, A. R., \& Picus, L. O. (2004). School finance: A policy perspective (Third edition ed.). Boston: McGraw-Hill. 
Romano, R. M. (2003, October 13-14). Financing community colleges across the states: An economic perspective. Paper presented at the The Complex Community College, Cornell Higher Education Research Institute, Cornell University, Ithaca, NY.

State funding for community colleges: A fifty state survey. (2000). Denver, Colorado: Center for Community College Policy, Education Commission of the States. Study: Hope and Lifetime Learning are middle-class tax benefits, not financial aid. (2003, March 14, 2003). Retrieved December 19, 2003, from www.NASFAA.org

Timar, T. B. (1994). Politics, policy, and categorical aid: New inequities in California school finance. Educational Evaluation and Policy Analysis, 16(2), 143-160.

Timar, T. B. (2003). School governance in California: You can't always get what you want. Retrieved April 30, 2003, from www.ucla-idea.org

Verstegen, D. A. (1998). Judicial analysis during the new wave of school finance litigation: The new adequacy in education. Journal of Education Finance, 24(Summer), 51-68.

Wong, K. K. (1994). Governance structure, resource allocation, and equity policy. Review of Research in Education, 20, 257-289. 
${ }^{1}$ See, for example, the web site of the Campaign for Fiscal Equity http://www.schoolfunding.info/ for a summary of recent legal actions and court decisions.

${ }^{1}$ Colleges with the word "technical" in their name were excluded. Other technical colleges may still remain in the sample.

${ }^{1}$ The excluded states and colleges are Alaska (2), Delaware (3), Idaho (3), Indiana (13 of 14 technical colleges), Kentucky (financial data reported for Lexington CC only), Maine (7 of 7 technical colleges), Montana (5 of 8 technical colleges), Nevada (3), Rhode Island (1), South Dakota (4), Utah (3), Vermont (1), West Virginia (3) and Wisconsin (16 of 17 technical colleges).

${ }^{1}$ The FTE calculation is based on the same ratio used to publish enrollment statistics in the annual Digest of Education Statistics. For the public two-year sector, the FTE equals full-time enrollment plus part-time enrollment multiplied by one-third.

${ }^{1}$ In California, "Districts receive a portion of the $1 \%$ countywide property tax based on their proportional share of property tax revenue received from their county prior to tax control (Prop. 13, 1978)” (State Funding, 2000, p. 12).

${ }^{1}$ To some extent, the variation in tuition and fees is due to mismeasurement at the college level. A review of reported tuition charges in Massachusetts, where the Board of Higher Education sets a uniform tuition, showed that individual colleges reported different tuition rates, in some cases due to different approaches to calculating full-time enrollment status. In this state, fees are set by the individual colleges and do create valid variation in the total of tuition and fees.

${ }^{1}$ The cases and values are Mid-South Community College, AR (\$26,648 per FTE above the state median of local and state appropriations), South Piedmont Community College, NC $(\$ 27,547)$, Coahoma Community College, MS ((\$15,516), Illinois Eastern Community Colleges-Olney Central College, IL $(\$ 13,491)$, and Foothill College, CA $(\$ 9,114)$.

${ }^{1}$ The 5 extreme cases are excluded from the calculation of average deviations.

${ }^{1}$ Alternatively, the use of an IQR exceeding \$1500 as a selection criterion would add Alabama, Massachusetts, and North Dakota as state-funded high disparity states and Arizona, Illinois, New Mexico, and Wyoming as high disparity local-funded states. 
Table 1 state and Local Appropriations per FTE

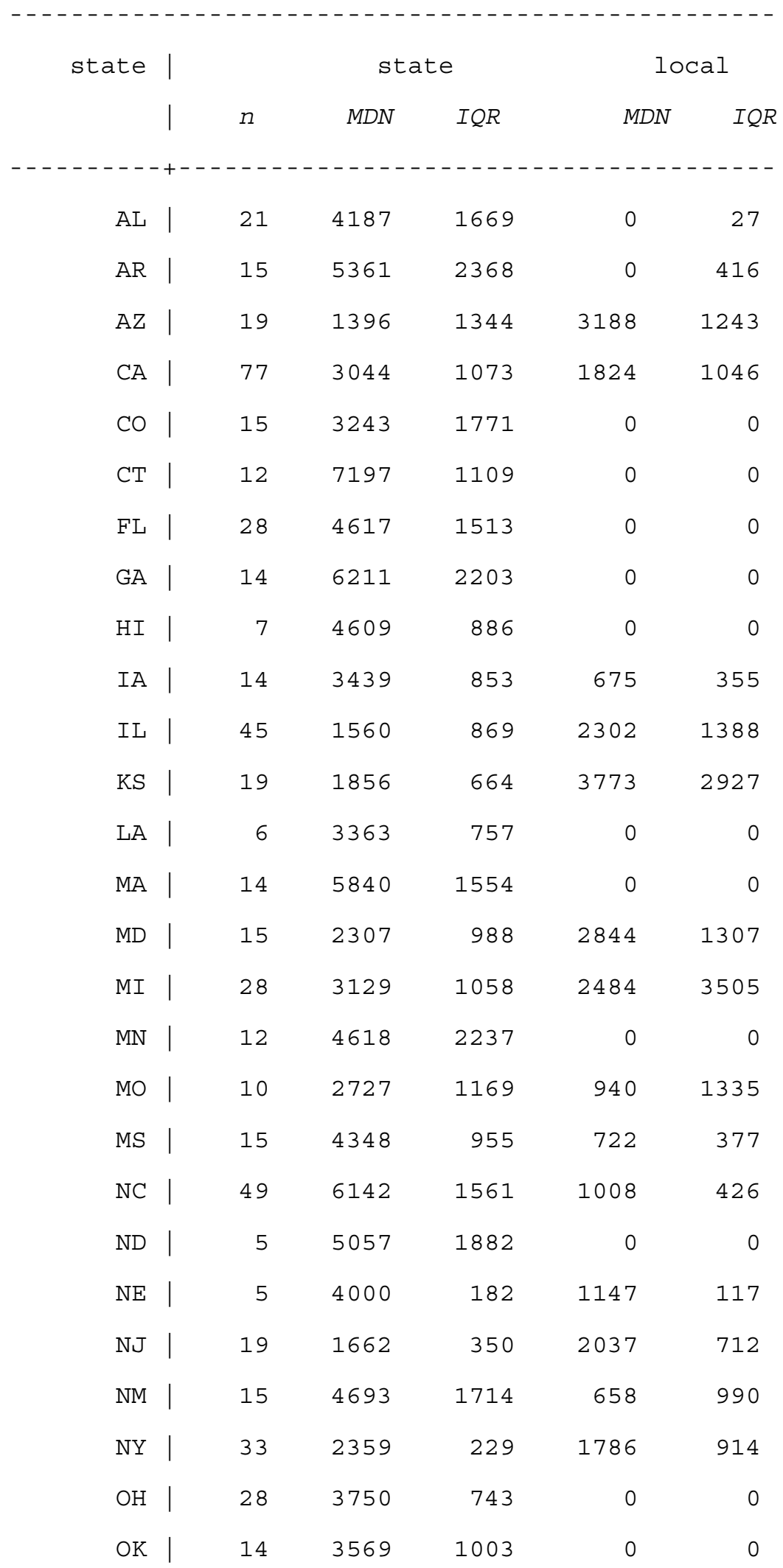


Community College Finance 31

\begin{tabular}{r|rrrrr} 
OR & 13 & 4222 & 1148 & 2209 & 688 \\
PA & 14 & 2495 & 312 & 1462 & 885 \\
SC | & 5 & 5401 & 737 & 0 & 0 \\
TN | & 10 & 3691 & 316 & 0 & 0 \\
TX | & 58 & 3432 & 1103 & 1194 & 1569 \\
VA & 24 & 4055 & 850 & 23 & 22 \\
WA & 27 & 3928 & 657 & 0 & 0 \\
WY & 7 & 4414 & 897 & 1365 & 1964
\end{tabular}

Source: NCES IPEDS 2000-01

Number of colleges in state based on $n$ reporting

financial data. 
Table 2 Distribution of Colleges by Funding Type by state

\begin{tabular}{|c|c|c|c|c|c|c|c|c|c|c|}
\hline \multirow[b]{2}{*}{ state | } & \multicolumn{5}{|c|}{----state-funded state $----_{-----}$} & \multicolumn{5}{|c|}{----local-share state $----_{---}$} \\
\hline & $0.0-$ & $0.02-$ & $0.51-$ & $1.1-$ & $>2.0$ & $0-$ & $0.02-$ & $0.51-$ & $1.1-$ & $>2.0$ \\
\hline $\mathrm{AL} \mid$ & 19 & 2 & & & & & & & & \\
\hline AR | & 11 & 4 & & & & & & & & \\
\hline $\mathrm{Az}$ & & & & & & & 1 & 1 & 5 & 12 \\
\hline $\mathrm{CO}$ & 13 & & & 1 & 1 & & & & & \\
\hline $\mathrm{CT} \mid$ & 12 & & & & & & & & & \\
\hline FL | & 28 & & & & & & & & & \\
\hline GA $\mid$ & 14 & & & & & & & & & \\
\hline $\mathrm{HI} \mid$ & 7 & & & & & & & & & \\
\hline IA $\mid$ & & & & & & 1 & 13 & & & \\
\hline IL & & & & & & & 6 & 9 & 13 & 13 \\
\hline $\mathrm{KS} \mid$ & & & & & & & 2 & 5 & 4 & 8 \\
\hline LA $\mid$ & 6 & & & & & & & & & \\
\hline MA $\mid$ & 14 & & & & & & & & & \\
\hline $\mathrm{MD} \mid$ & & & & & & 1 & & 5 & 8 & 1 \\
\hline MI | & & & & & & 6 & 5 & 5 & 9 & 3 \\
\hline MN | & 12 & & & & & & & & & \\
\hline MO | & & & & & & 1 & 6 & 3 & & \\
\hline MS | & & & & & & & 15 & & & \\
\hline $\mathrm{NC} \mid$ & & & & & & & 46 & & & \\
\hline ND $\mid$ & 5 & & & & & & & & & \\
\hline $\mathrm{NE} \mid$ & & & & & & & 5 & & & \\
\hline NJ | & & & & & & & & 7 & 11 & 1 \\
\hline NM | & & & & & & 2 & 9 & 4 & & \\
\hline NY | & & & & & & & 4 & 20 & 8 & 1 \\
\hline $\mathrm{OH} \mid$ & 22 & 3 & 2 & 1 & & & & & & \\
\hline OK | & 12 & 1 & 1 & & & & & & & \\
\hline OR | & & & & & & & 7 & 5 & 1 & \\
\hline $\mathrm{PA} \mid$ & & & & & & & 7 & 7 & & \\
\hline $\mathrm{SC} \mid$ & 5 & & & & & & & & & \\
\hline $\mathrm{TN}$ & 10 & & & & & & & & & \\
\hline $\mathrm{TX} \mid$ & & & & & & 7 & 34 & 13 & 3 & 1 \\
\hline
\end{tabular}




\begin{tabular}{|c|c|c|c|c|c|c|c|c|c|c|}
\hline $\mathrm{VA}$ & 24 & & & & & & & & & \\
\hline WA & 27 & & & & & & & & & \\
\hline WY & & & & & & & 5 & 1 & 1 & \\
\hline${ }^{*} \mathrm{CA}$ & & & & & & 9 & 24 & 33 & 5 & 6 \\
\hline otal | & 241 & 10 & 3 & 2 & 1 & 18 & 165 & 85 & 63 & 40 \\
\hline
\end{tabular}

Source: NCES IPEDS 2000-01

Number of colleges in state based on $\mathrm{n}$ reporting

financial data. Local-share categories represent a ratio of local-to-

state appropriations of 0.0-0.01, 0.02-0.50,.51-1.0, 1.1-2.0,>2.0.

Local-share states include those with at least $75 \%$ of colleges

reporting a ratio of local-to-state appropriations $>=0.02$

*CA colleges report local shares, but the state, which includes a large

proportion of U.S. community colleges, is examined separately. 
Table 3 Tuition and Fees and Federal Grant Aid by Funding Type and state

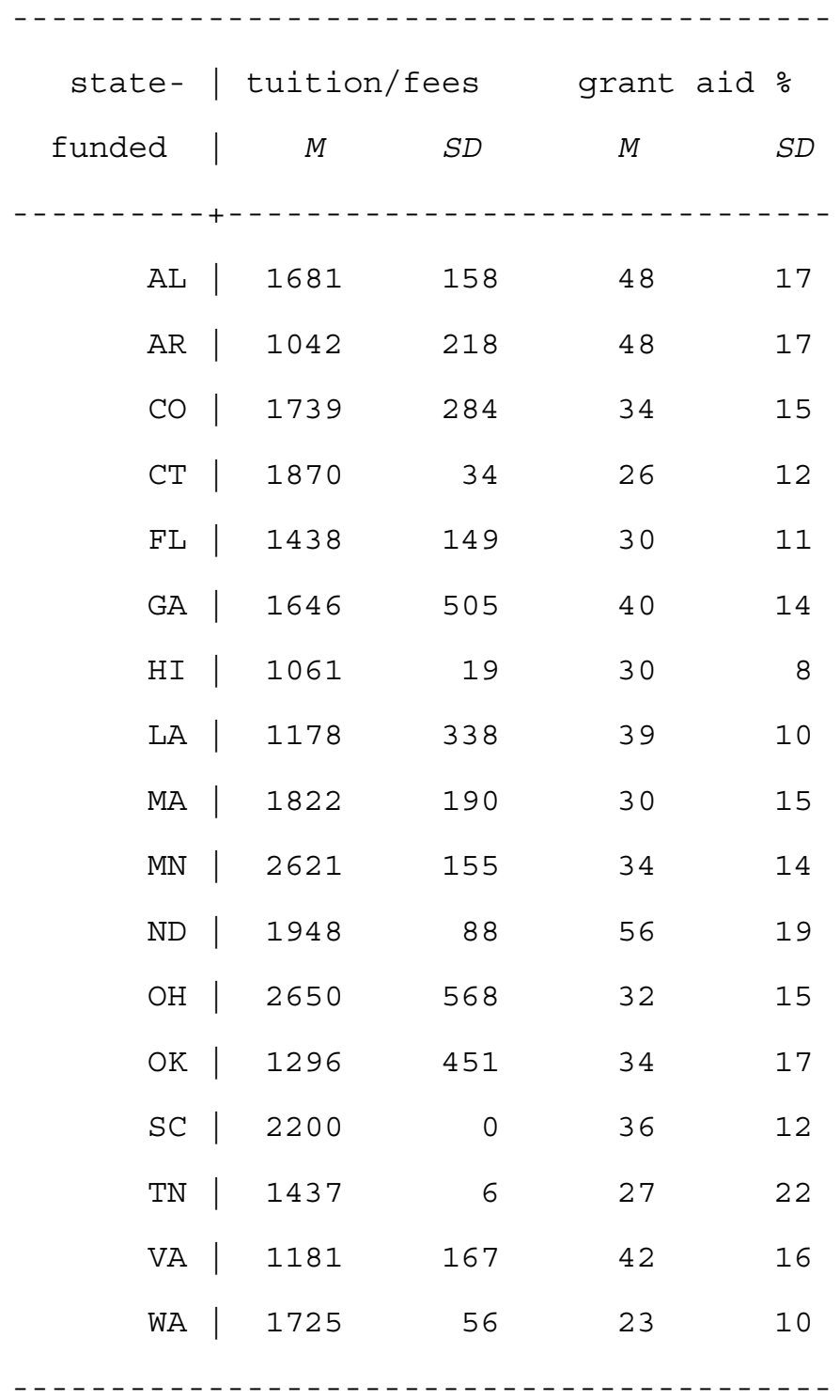




\begin{tabular}{|c|c|c|c|c|}
\hline \multirow{2}{*}{$\begin{array}{l}\text { local- } \\
\text { funded }\end{array}$} & \multicolumn{2}{|c|}{ tuition/fees } & \multicolumn{2}{|c|}{ grant aid \% } \\
\hline & $M$ & $S D$ & $M$ & $S D$ \\
\hline----- & ---- & --- & --- & ---- \\
\hline $\mathrm{AZ}$ & 910 & 105 & 38 & 19 \\
\hline IA & 2208 & 220 & 36 & 14 \\
\hline IL & 1522 & 190 & 29 & 19 \\
\hline KS & 1387 & 119 & 34 & 10 \\
\hline $\mathrm{MD}$ & 2165 & 436 & 33 & 19 \\
\hline MI & 1754 & 378 & 32 & 15 \\
\hline $\mathrm{MO}$ & 1504 & 271 & 38 & 15 \\
\hline MS & 1144 & 358 & 54 & 12 \\
\hline $\mathrm{NC}$ & 897 & 64 & 42 & 18 \\
\hline $\mathrm{NE}$ & 1429 & 95 & 42 & 27 \\
\hline $\mathrm{NJ}$ & 2284 & 448 & 36 & 18 \\
\hline $\mathrm{NM}$ & 808 & 392 & 52 & 16 \\
\hline NY & 2560 & 248 & 49 & 14 \\
\hline OR & 1726 & 230 & 36 & 18 \\
\hline $\mathrm{PA}$ & 2156 & 294 & 26 & 12 \\
\hline $\mathrm{TX}$ & 874 & 275 & 37 & 21 \\
\hline WY & 1469 & 109 & 34 & 11 \\
\hline
\end{tabular}

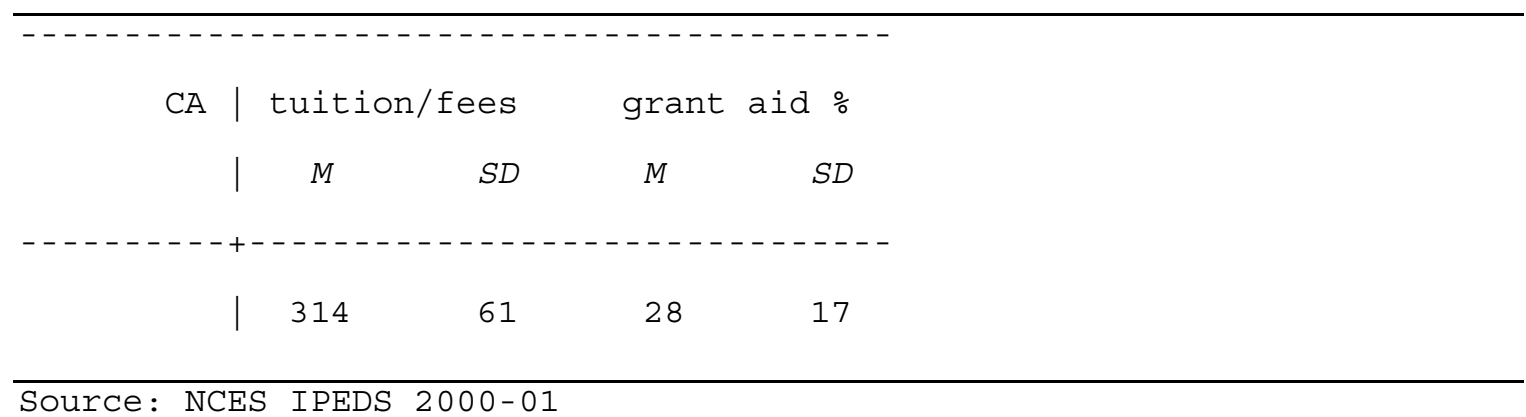




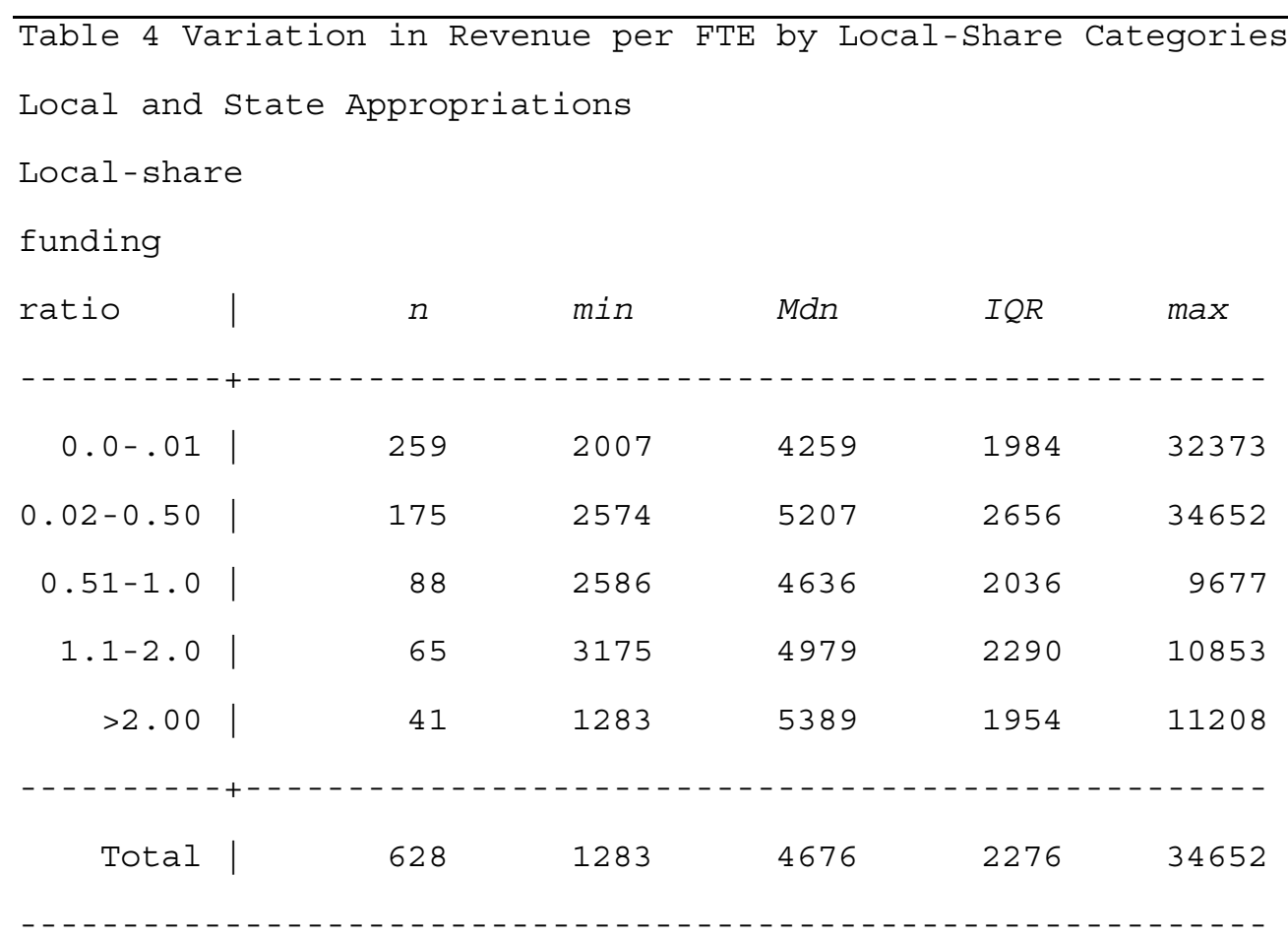

Total Revenues, minus Tuition and Fees

Local-share

funding

\begin{tabular}{|c|c|c|c|c|c|}
\hline ratio & $n$ & min & $M d n$ & $I Q R$ & $\max$ \\
\hline $0.0-0.01$ & 259 & 3182 & 7454 & 3132 & 58690 \\
\hline $0.02-0.50$ & 175 & 3840 & 8459 & 2839 & 47286 \\
\hline $0.51-1.0$ & 88 & 4444 & 7390 & 2791 & 14054 \\
\hline $1.1-2.0$ & 65 & 4720 & 7347 & 3181 & 13931 \\
\hline$>2.00$ & 41 & 3373 & 8059 & 3246 & 15550 \\
\hline Total & 628 & 3182 & 7715 & 3121 & 58690 \\
\hline
\end{tabular}

Source: NCES IPEDS 2000-01 
Table 5 Variation in local and state appropriations per FTE by Funding Type and state

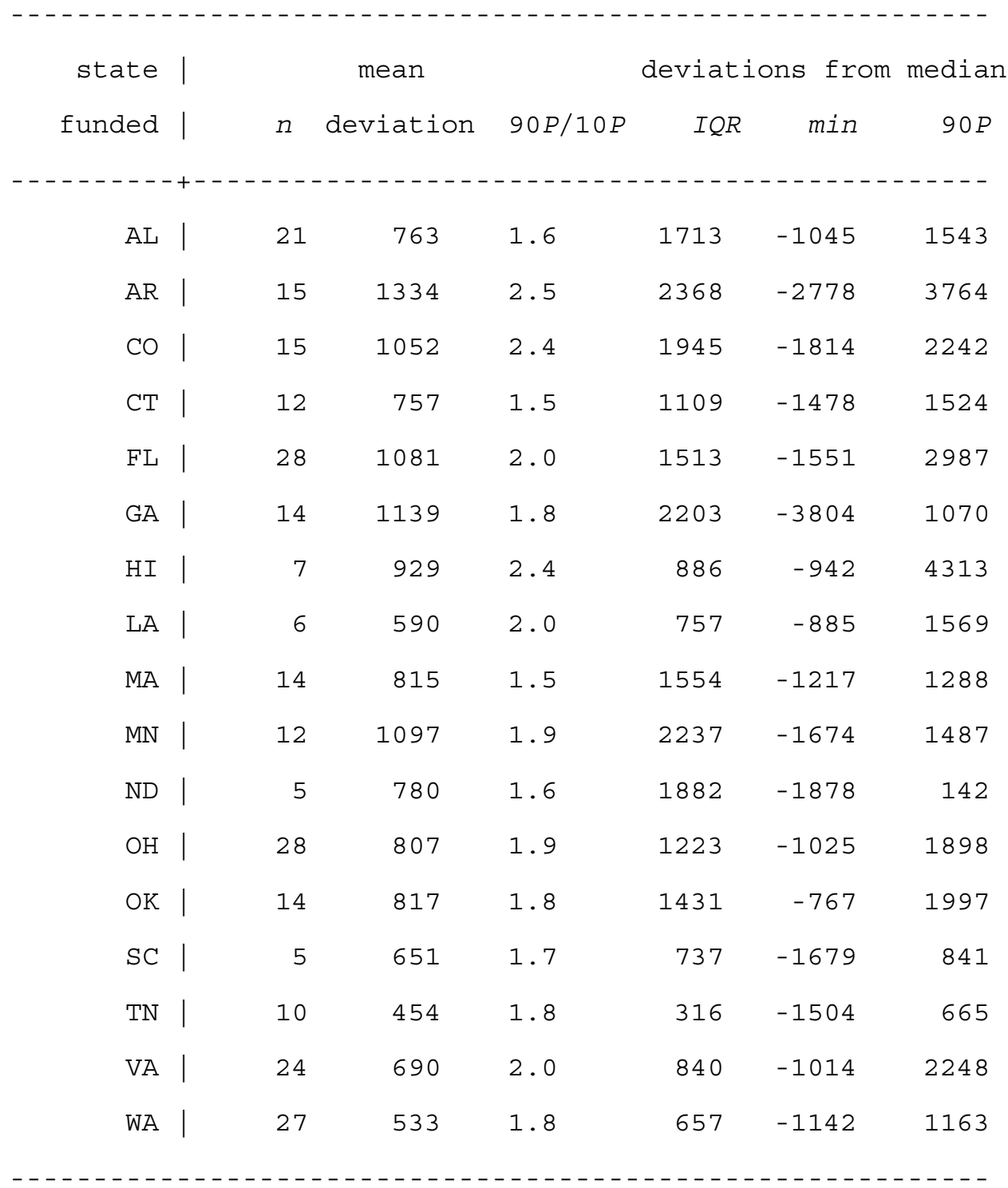


Community College Finance 38

\begin{tabular}{|c|c|c|c|c|c|c|c|}
\hline local | & & mean & & devi & Eions frc & rom med & lian \\
\hline funded | & $n$ & deviation & $90 P / 10 P$ & $I Q R$ & $\min$ & $90 P$ & \\
\hline $\mathrm{AZ}$ & 19 & 846 & 2.0 & 1796 & -1441 & 1749 & \\
\hline IA & 14 & 792 & 1.8 & 769 & -1026 & 2866 & \\
\hline IL $\mid$ & 45 & 904 & 1.9 & 1303 & -2781 & 1925 & \\
\hline $\mathrm{KS}$ & 19 & 1266 & 2.1 & 2549 & -2025 & 2003 & \\
\hline $\mathrm{MD} \mid$ & 15 & 1128 & 2.2 & 1425 & -1485 & 4077 & \\
\hline MI | & 28 & 1467 & 2.8 & 2788 & -3558 & 2555 & \\
\hline MO | & 10 & 334 & 1.4 & 705 & -523 & 671 & \\
\hline MS | & 15 & 517 & 1.4 & 1052 & -1503 & 1327 & \\
\hline $\mathrm{NC}$ & 49 & 1472 & 2.0 & 1827 & -2598 & 2381 & \\
\hline $\mathrm{NE} \mid$ & 5 & 753 & 1.8 & 299 & -686 & 2778 & \\
\hline NJ $\mid$ & 19 & 633 & 1.6 & 755 & -1270 & 1571 & \\
\hline NM | & 15 & 1360 & 2.1 & 1800 & -3623 & 1955 & \\
\hline NY | & 33 & 872 & 1.7 & 1103 & -1435 & 1471 & \\
\hline OR $\mid$ & 13 & 856 & 1.4 & 1132 & -1564 & 970 & \\
\hline $\mathrm{PA} \mid$ & 14 & 551 & 1.6 & 1088 & -733 & 1250 & \\
\hline $\mathrm{TX} \mid$ & 58 & 1350 & 2.4 & 2341 & -2241 & 2792 & \\
\hline WY | & 7 & 697 & 1.4 & 1912 & -603 & 1698 & \\
\hline \multirow[t]{3}{*}{$\mathrm{CA}$} & \multicolumn{3}{|c|}{ mean } & \multirow{2}{*}{\multicolumn{2}{|c|}{$\begin{array}{l}\text { deviations } \\
I Q R\end{array}$}} & from $n$ & median \\
\hline & $n$ & deviation & $90 P / 10 P$ & & & $\min$ & $90 P$ \\
\hline & 77 & 1330 & 2.5 & & 488 & -4748 & 2036 \\
\hline
\end{tabular}

Source: NCES IPEDS 2000-01

Mean deviation equals the sum of the absolute value of deviations from the state median divided by the number of colleges with non-missing data in the state. $90 P / 10 P$ is the $90^{\text {th }}$ percentile/ $10^{\text {th }}$ percentile ratio. 
Table 6 Variation in Revenue Deviations by Funding Type

In Dollars

\begin{tabular}{|c|c|c|c|c|c|c|c|}
\hline 1 & $n$ & $\min$ & $25 P$ & $\operatorname{Mdn}$ & $75 P$ & $90 P$ & $\max$ \\
\hline state funded | & 256 & 454 & 690 & 807 & 1081 & 1139 & 1334 \\
\hline local funded | & 368 & 334 & 846 & 904 & 1350 & 1472 & 1472 \\
\hline Total & 624 & 334 & 763 & 872 & 1334 & 1467 & 1472 \\
\hline
\end{tabular}

Revenue index

| $n \quad \min \quad 25 P \quad M d n \quad 75 P \quad 90 P \quad \max$

\begin{tabular}{|c|c|c|c|c|c|c|c|c|}
\hline state & funded & 256.00 & 0.39 & 0.86 & 1.00 & 1.14 & 1.37 & 2.15 \\
\hline local & funded & 368.00 & 0.32 & 0.89 & 1.00 & 1.19 & 1.38 & 2.60 \\
\hline & Total & 624.00 & 0.32 & 0.74 & 1.00 & 1.16 & 1.38 & 2.60 \\
\hline
\end{tabular}

Source: NCES IPEDS 2000-01

$n$ is based on sample with non-missing data, excluding California.

The revenue index is the absolute value of college revenue deviations as a proportion of the state median. 
Figure 1 State variation in tuition and fees by state and local funding. The lower and upper bounds of the box represent the $25^{\text {th }}$ and $75^{\text {th }}$ percentiles and the center line is the median. Each vertical line under the boxes represents the location of a state in the distribution of values. The scale differs for the range and IQR plots. Not all state cases are visible, due to overlapping values for some states.

Figure 2 Local and state appropriations (top panel) and revenues from all sources excluding tuition (lower panel) per FTE by college ratio of local appropriations to state appropriations. The width of the boxes corresponds to the proportion of cases in each category. The lower and upper bounds of the box represent the $25^{\text {th }}$ and $75^{\text {th }}$ percentile, the center line is the median, and the circles beyond the whiskers are outliers. Five extreme values are omitted, excluding one case in 0.0-0.01 and 4 in $0.02-0.50$ categories.

Figure 3 Average absolute deviations per FTE by state and local funding. The lower and upper bounds of the box represent the $25^{\text {th }}$ and $75^{\text {th }}$ percentiles and the center line is the median. Each vertical line under the boxes represents the location of a state in the distribution of values.

Figure 4 Revenue deviations by grant receipt in state-funded states, with geographic locale as case marker. The $y$-axis scale differs by state.

Figure 5 Revenue deviations by grant receipt in local-share states, with positive associations. Geographic locale is the case marker. The y-axis scale differs by state.

Figure 6 Revenue deviations by grant receipt in local-share states, with no association. Geographic locale is the case marker. The y-axis scale differs by state. 


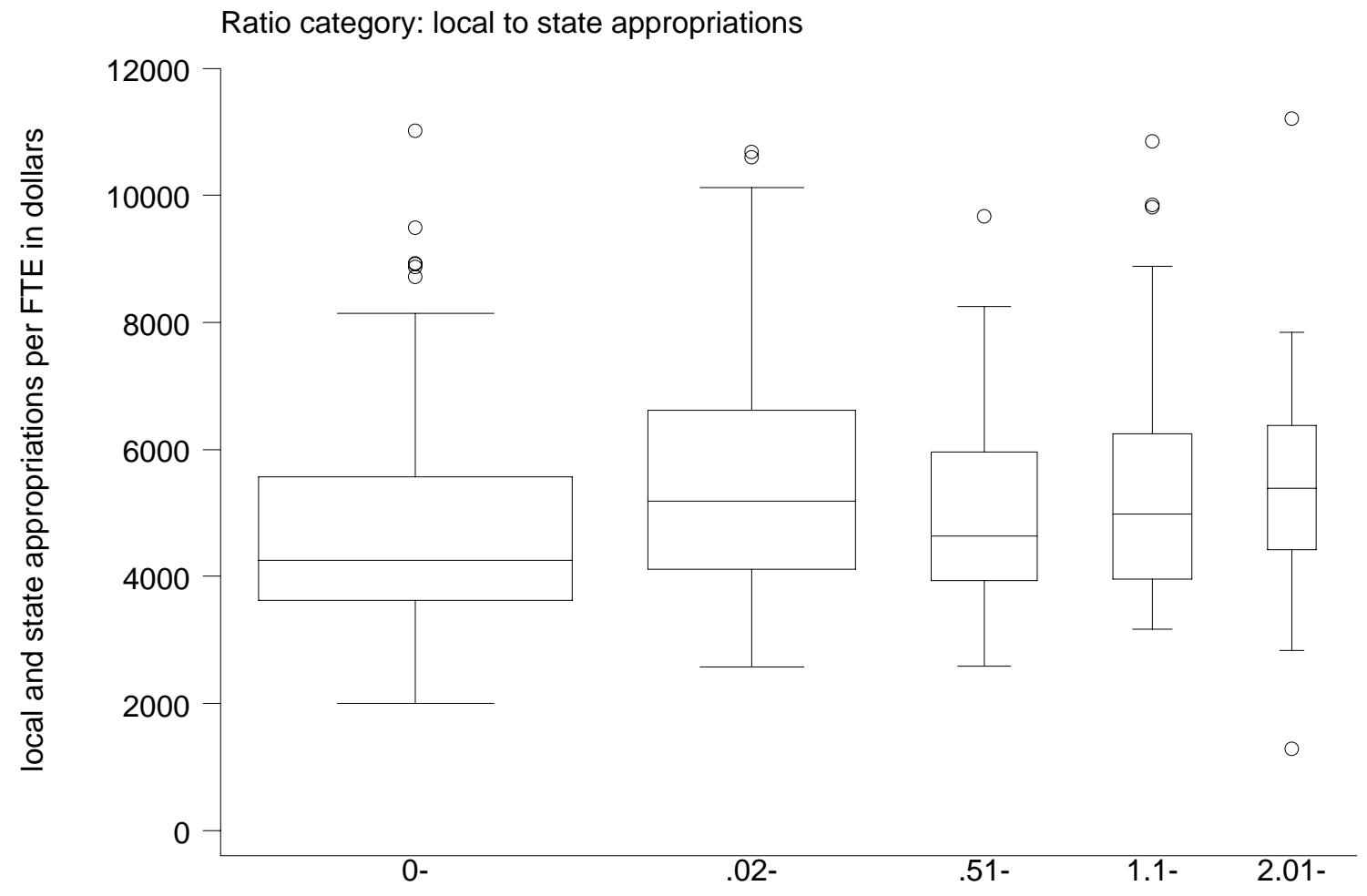

Ratio category: local to state appropriations

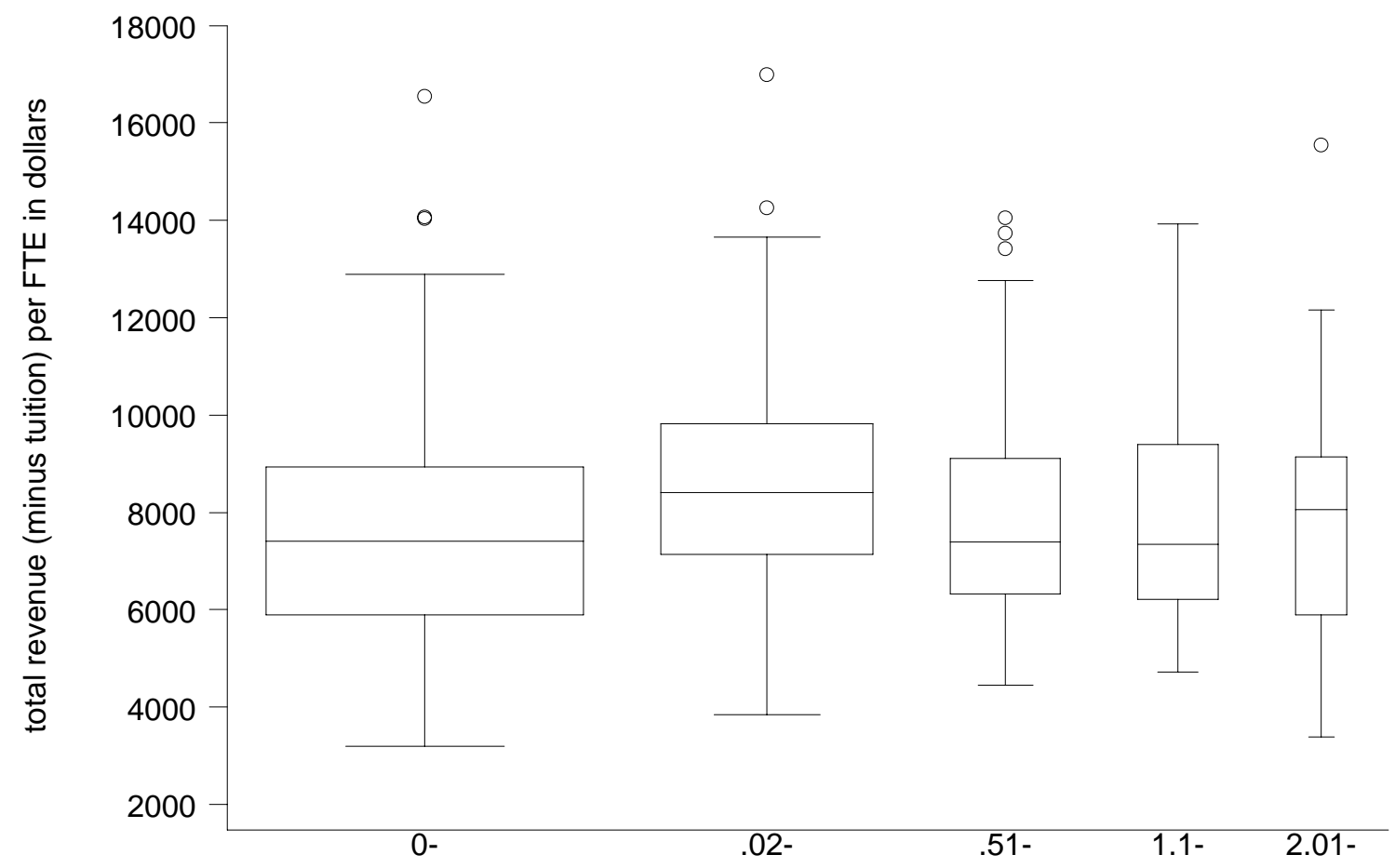




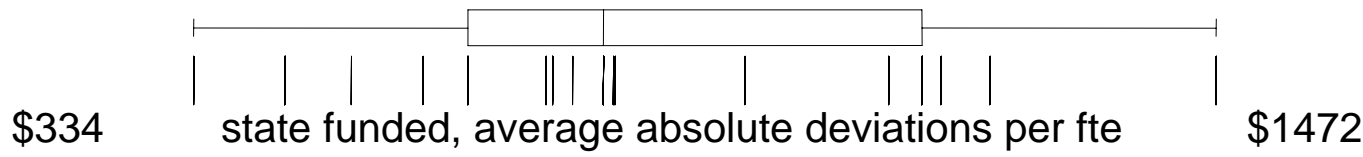

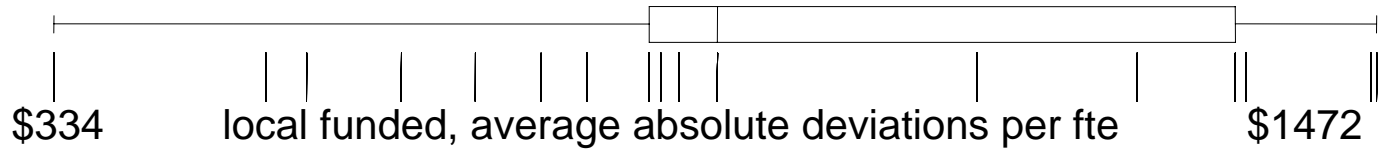



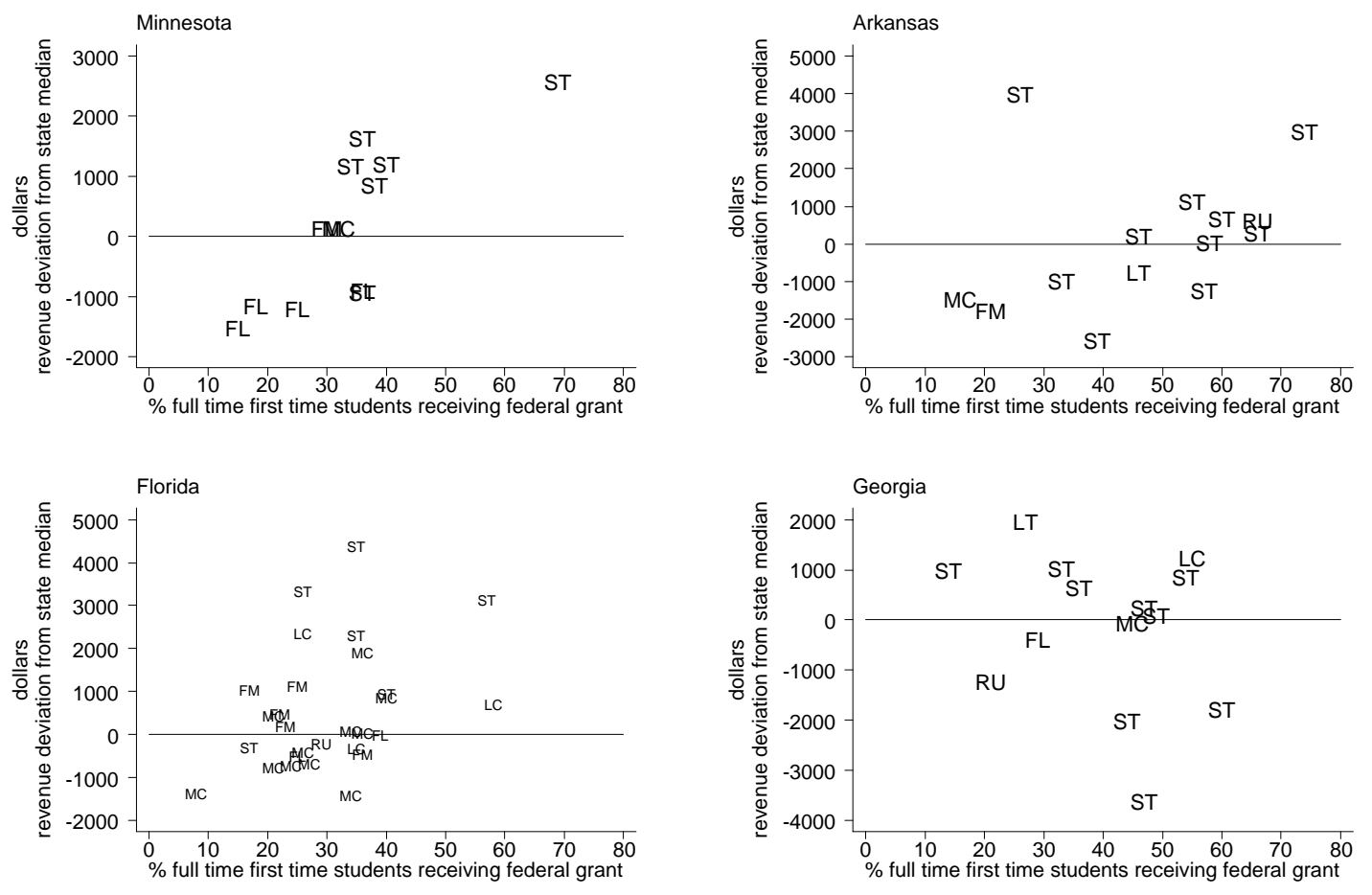

LC large city, MC midsize city, FL fringe large city, FM fringe midsize city, LT large town, ST small town, $\mathrm{R}$ rural 

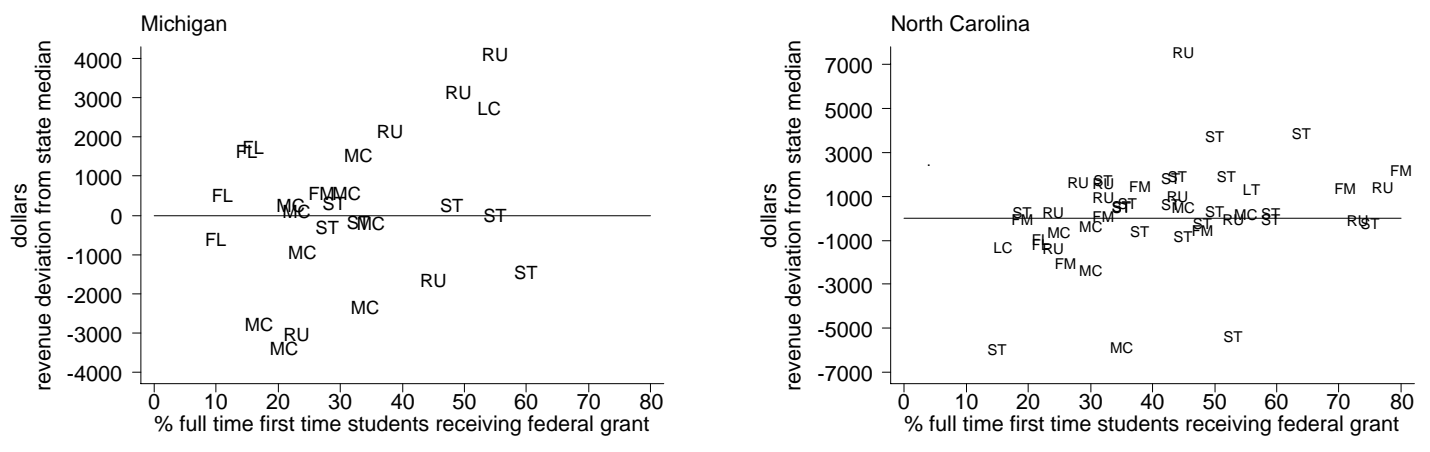

LC large city, MC midsize city, FL fringe large city, FM fringe midsize city, LT large town, ST small town, $\mathrm{R}$ rural 

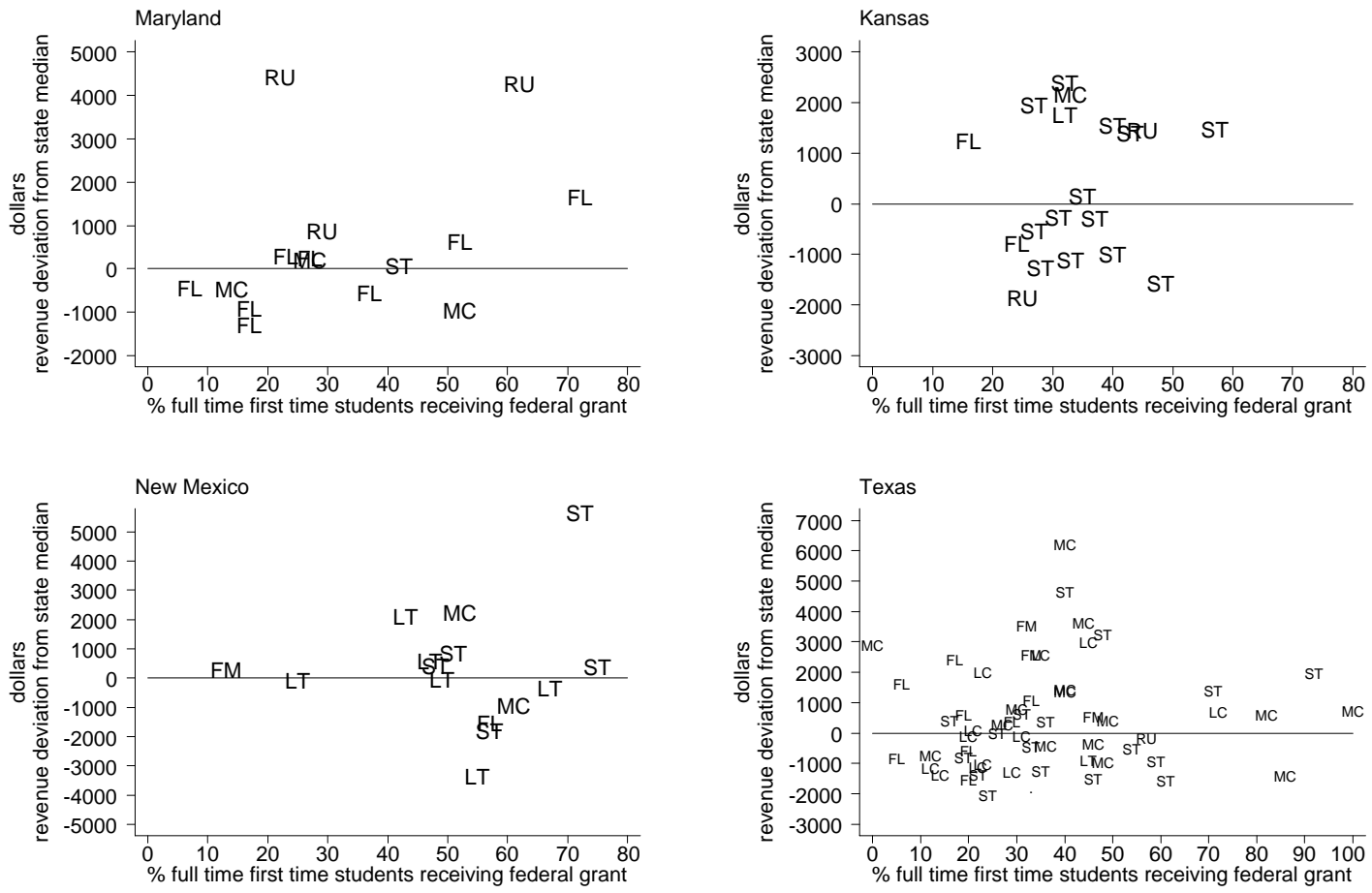

LC large city, MC midsize city, FL fringe large city, FM fringe midsize city, LT large town, ST small town, $\mathrm{R}$ rural 
${ }^{1}$ See, for example, the web site of the Campaign for Fiscal Equity http://www.schoolfunding.info/ for a summary of recent legal actions and court decisions.

${ }^{2}$ Colleges with the word "technical” in their name were excluded. Other technical colleges may still remain in the sample.

${ }^{3}$ The excluded states and colleges are Alaska (2), Delaware (3), Idaho (3), Indiana (13 of 14 technical colleges), Kentucky (financial data reported for Lexington CC only), Maine (7 of 7 technical colleges), Montana (5 of 8 technical colleges), Nevada (3), Rhode Island (1), South Dakota (4), Utah (3), Vermont (1), West Virginia (3) and Wisconsin (16 of 17 technical colleges).

${ }^{4}$ The FTE calculation is based on the same ratio used to publish enrollment statistics in the annual Digest of Education Statistics. For the public two-year sector, the FTE equals full-time enrollment plus part-time enrollment multiplied by one-third.

${ }^{5}$ In California, "Districts receive a portion of the $1 \%$ countywide property tax based on their proportional share of property tax revenue received from their county prior to tax control (Prop. 13, 1978)" (State Funding, 2000, p. 12).

${ }^{6}$ To some extent, the variation in tuition and fees is due to mismeasurement at the college level. A review of reported tuition charges in Massachusetts, where the Board of Higher Education sets a uniform tuition, showed that individual colleges reported different tuition rates, in some cases due to different approaches to calculating full-time enrollment status. In this state, fees are set by the individual colleges and do create valid variation in the total of tuition and fees.

${ }^{7}$ The cases and values are Mid-South Community College, AR (\$26,648 per FTE above the state median of local and state appropriations), South Piedmont Community College, NC $(\$ 27,547)$, Coahoma Community College, MS ((\$15,516), Illinois Eastern Community Colleges—Olney Central College, IL $(\$ 13,491)$, and Foothill College, CA $(\$ 9,114)$.

${ }^{8}$ The five extreme cases are excluded from the calculation of average deviations.

${ }^{9}$ Alternatively, the use of an IQR exceeding \$1500 as a selection criterion would add Alabama, Massachusetts, and North Dakota as state-funded high disparity states and Arizona, Illinois, New Mexico, and Wyoming as high disparity local-funded states. 
(n) 